\title{
Izobraževanje managerjev za delo v tujini
}

dr. Sonja

Treven

Ekonomsko-

poslovna fakulteta

v Mariboru podjetjih, ki poslujejo v drugih državah, se srečujejo, poleg s problemi na področju izbire, nagrajevanja in reintegracije izseljenih managerjev, tudi s problemom njihovega izobraževanja. Ker ti znatno pripomorejo $\mathrm{k}$ doseganju ciljev podjetja, se njihovega pomena ne sme zanemariti ali premalo upoštevati.

Ko je manager, ki bo upravljal posle podjetja v drugi državi, izbran, ga je treba pripraviti na delo v novem okolju. Ker že ima spretnosti, ki se nanašajo na delo in so potrebne za njegovo opravljanje, se takšne priprave običajno nanašajo na medkulturno izobraževanje. Manager se mora pred odhodom v tujino namreč seznaniti s kulturo države gostiteljice, da se bo v njej ustrezno vedel. Spoznati mora različne oblike vedenja in medsebojnih odnosov, ki so v tej državi sprejemljivi na poslovnih sestankih in družabnih srečanjih. Poleg tega se mora naučiti, kako pravilno komunicirati v novem kulturnem okolju (Treven, 1998).

V prispevku bomo najprej predstavili dva različna pristopa $\mathrm{k}$ preučevanju kulture. Izhajali bomo iz Hofstedove opredelitve razsežnosti kulture in Kluckhohnovih ter Strodtbeckovih razlik $\mathrm{v}$ vrednotah. $\mathrm{V}$ nadaljevanju bomo pozornost usmerili na povezanost kulture $\mathrm{z}$ organizacijskim vedenjem. Prikazali bomo, kako kultura vpliva na motivacijo zaposlenih v organizacijah, način komuniciranja in oblikovanje ter dejavnost delovnih timov. Prispevek bomo zaokrožili s prikazom nekaterih metod, ki jih je mogoče uporabiti pri izobraževanju managerjev o različnih kulturah.

\section{RAZLIČNI PRISTOPI K PREUČEVANJU KULTURE}

Znanstveniki so za preučevanje kultur oblikovali različne modele, $v$ katerih so predstavili sisteme vrednot, značilnih za posamezne kulture. Na podlagi teh modelov lahko managerji pričakujejo, kakšno bo vedenje posameznikov z enako kulturo. Vendar je treba upoštevati, da se posamezniki z enako kulturo (na primer Slovenci) ne vedejo enako. Pogosto se med njimi pojavijo večje razlike kot pri posameznikih, ki se jih uvršča v drugo kulturo.

\section{Hofstedejeva opredelitev kulture}

Geert Hofstede se je pri raziskovanju kulture usmeril predvsem na vrednote, povezane $\mathrm{z}$ delom. Podatke je pridobil od delavcev iz štirideset različnih držav, zaposlenih pri IBM. Ko je analiziral podatke od več kot 116.000 zaposlenih, je izbral pet razsežnosti vrednot, s katerimi je skušal razložiti razlike med kulturami.

Prva razsežnost se nanaša na moč povezave med posamezniki v družbi in je opredeljena s stopnjo, do katere se ti raje vedejo kot posamezniki kot pa člani skupine. Druga razsež-

Različne kulture lahko med seboj primerjamo in jih razvrstimo na podlagi naslednjih razsežnosti (Hofstede, 1991):

- individualizem/kolektivizem,

- razdelitev moěi,

- premagovanje negotovosti,

- moška ali ženska utemeljenost,

- kratko- ali dolgoročna usmerjenost. 
nost, razdelitev moči, opredeljuje razmerja med hierarhično razdelitvijo moči v družbi in prikazuje stopnjo neenakosti, ki jo člani skupnosti še priznavajo kot normalno. Tretja razsežnost, premagovanje negotovosti, se nanaša na razmerje posamezne kulture do negotovosti, povezane s prihodnostjo. Četrta razsežnost je povezana $\mathrm{z}$ delitvijo vlog med spoloma v družbi. V moško utemeljenih kulturah prevladujejo tradicionalno moške vrednote, $\mathrm{v}$ žensko usmerjenih pa zagovarjajo tradicionalno ženske vrednote. Zadnja med omenjenimi razsežnostmi izhaja iz daljnovzhodne filozofije in se nanaša na dolgoročno ali kratkoročno usmeritev posamezne kulture.

\section{Kluckhohnove in Strodtbeckove razlike $\mathbf{v}$ vrednotah}

Ameriška antropologa Kluckhohn in Strodtbeck sta uporabila šest razsežnosti vrednot, $\mathrm{s}$ katerimi sta opisala usmeritve v različnih kulturah. Temeljne usmeritve vrednot in možne različice $\mathrm{v}$ okviru posamezne usmeritve so prikazane v tabeli 1 . Kluckhohn in Strodtbeck menita, da $v$ določeni kulturi prevladujeta ena ali dve različici, povezani s posamezno usmeritvijo vrednot.

\begin{tabular}{|c|c|c|c|}
\hline Usmeritev vrednot & & Razlicice & \\
\hline Rozmerie do narave & Podrejanie & Hamonila & Obrladovenje \\
\hline Casovna usmetienost & Preteklost & Sedanjost & Prhodnost \\
\hline Cloveska narava & Hudobna & Nevtralno & Dobra \\
\hline Usmerjenost k delovan'y & Zodovolistvo & Nadzor & Delo \\
\hline Povezove med posamezniki & lneividudistiche & Kolekixne & Herahtine \\
\hline Prostorske usmerienost & Zosebno & Konbinicha & Jovin \\
\hline
\end{tabular}

$\mathrm{V}$ razmerju do narave so posamezne kulture usmerjene k podrejanju zakonitostim narave, druge $\mathrm{k}$ harmonični povezanosti $\mathrm{z}$ naravo in tretje $\mathrm{k}$ njenemu obvladovanju. S časovnega vidika so posamezne kulture usmerjene $\mathrm{V}$ preteklost, sedanjost ali prihodnost. V okviru usmerjenosti $\mathrm{k}$ temeljni človeški naravi je za ene kulture značilno, da so posamezniki dobri, za druge, da so hudobni, za tretje, da je $\mathrm{v}$ njih kombinacija dobrega in zla. $\mathrm{Z}$ vidika usmerjenosti $\mathrm{k}$ delovanju razlikujemo kulture, ki cenijo sedanjost in občutek zadovoljstva v tem trenutku, druge, ki poudarjajo delo, in tretje, ki poveličujejo nadzor nad samim seboj. Naslednja usmeritev se nanaša na povezave med posamezniki. Te so lahko individualistične, kolektivne ali hierarhične. Zadnja, prostorska usmerjenost se nanaša na razmerje posameznikov do prostora. Ti lahko dojemajo prostor kot javno, zasebno ali mešano lastnino.

\section{POVEZANOST KULTURE Z ORGANIZACIJSKIM VEDENJEM}

Poznavanje kulture, čeprav ta ni edini pomemben dejavnik, managerjem zelo pomaga pri razumevanju razlik v družbenem vedenju. Bolje lahko razumejo tudi management in organizacijsko vedenje $v$ različnih predelih sveta, če upoštevajo vlogo, ki jo ima kultura $\mathrm{v}$ njihovih organizacijah.

\section{Razlike v kulturi in motivacija}

Kultura države, v kateri delujejo organizacije, zelo vpliva na način motiviranja njihovih zaposlenih. V kolektivno zasnovanih kulturah je na primer zaposleni neprijetno presenečen, če mu bodo $\mathrm{v}$ podjetju ponudili individualno nagrado za njegove dosežke in uspešno delo. $\mathrm{V}$ teh kulturah imajo pogosto oblikovane norme o vedenju $\mathrm{v}$ določenih okoliščinah. Če skušajo zaposlenemu dati individualno nagrado, je to $\mathrm{v}$ nasprotju s skupinskimi norma$\mathrm{mi}$, zato je malo verjetno, da bo to pozitivno učinkovalo na njegovo motivacijo.

Način motiviranja zaposlenih se razlikuje tudi v moško in žensko utemeljenih kulturah. V prvi zaposleni cenijo denarne nagrade, nagrade $v$ obliki nazivov in druge statusne ali materialne nagrade. $\mathrm{V}$ žensko utemeljeni kulturi pa so pomembnejše nagrade prosti čas, večje 
ugodnosti pri delu in simbolične nagrade, ki izražajo pozornost do zaposlenih.

Dejavniki, ki motivirajo zaposlene v organizacijah, niso odvisni samo od posamezne kulture, temveč so pogosto različni tudi $\mathrm{v}$ okviru določene kulture. Katere nagrade cenijo zaposleni v Sloveniji ali na Hrvaškem, tako ni samo odsev kulture Slovencev in Hrvatov, temveč tudi drugih dejavnikov, na primer starosti, spola, izobrazbe zaposlenih in organizacijske ravni, na kateri ti opravljajo svoje delo.

\section{Vpliv kulture na način komuniciranja}

V različnih kulturah posamezniki tudi komunicirajo med seboj različno. Razlike pri načinu komuniciranja lahko povežemo predvsem $\mathrm{z}$ uporabo jezika, v katerem se izražajo, verbalnim stilom, ki ga pri tem uporabljajo, in neverbalnim delom komunikacije.

\section{Delovni timi v različnih kulturah}

Kulture zelo vplivajo na oblikovanje in delovanje delovnih timov v organizacijah (Treven, 2000). Na Japonskem odsevajo na primer timi njihove kolektivne kulturne vrednote. Koreja je primer azijske kulture, v kateri ne namenjajo veliko pozornosti vlogi timov v organizacijah, v Izraelu pa demokratične delovne skupine delujejo kot timi in v svoje delo prenašajo pomembne družbene vrednote.

Oglejmo si podrobneje, kakšna je vloga delovnih timov v teh treh državah. Na Japonskem na primer uporabljajo $\mathrm{v}$ organizacijah timski način odločanja, ki ga imenujejo »ringisei «, tj. odločanje s soglasjem. Vendar $\mathrm{v}$ vseh azijskih kulturah timi ne odločajo v organizacijah. V Koreji, v kateri delujejo velika družinska podjetja, je timsko odločanje prej izjema kot pravilo. Za Izrael pa so značilni kibuci, to so kolektivna posestva ali podjetja, v katerih gre za demokratično sodelovanje na vseh področjih delovanja. Temeljna načela kibuca so družbena lastnina vseh materialnih virov, popolna enakopravnost med člani, demokratično odločanje, skupna odgovornost za varstvo otrok in prednost skupine pred posamezniki (Gannon, 1994).

\section{METODE IZOBRAŽEVANIA O RAZLIČNIH KULTURAH}

Omenili smo že, da so izseljeni managerji uspešnejši, če jih v njihovih organizacijah ustrezno usposobijo za delo in življenje $\mathrm{v}$ tujini. Najpomembnejši razlog za njihov neuspeh je pomanjkljivo izobraževanje (Treven, 2001).

Temeljni vidik njihovega izobraževanja je spoznavanje različnih kultur (cross-cultural training). Tako izobraževanje jih pripravi na delo in življenje $v$ drugačnem kulturnem okolju. Srečanje z novo kulturo in novim okoljem je zanje veliko večji problem kot obvladovanje novega dela. Pri njihovem izobraževanju se lahko uporabljajo različne metode.

\begin{tabular}{|c|c|}
\hline Metoda & Namen \\
\hline Navodila o kulluri & 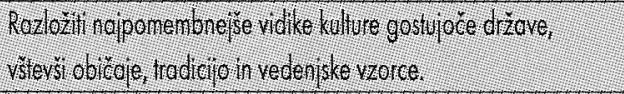 \\
\hline Navodila o podroçu & 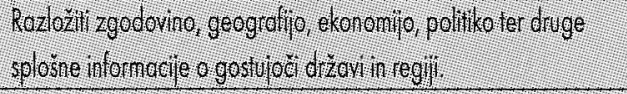 \\
\hline Preucevonje primerov & 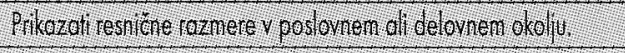 \\
\hline Igronje vlog & 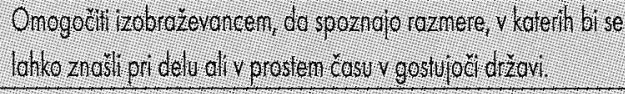 \\
\hline - Kulluni osimilalor & 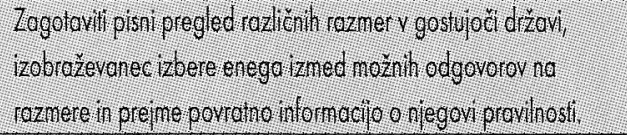 \\
\hline - lekusnje s podrocia & 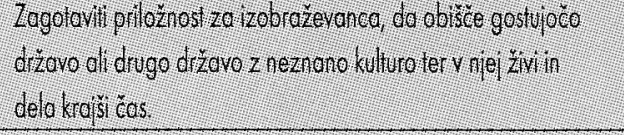 \\
\hline
\end{tabular}

V organizaciji lahko izberejo najprimernejšo metodo izobraževanja na podlagi treh dejavnikov, povezanih $\mathrm{z}$ vlogo izseljenega managerja. To so:

- nepoznavanje kulture, 
- stopnja interakcije s prebivalci gostujoče države in

- novost pri delu.

Nepoznavanje kulture se nanaša na različnost med novo kulturo in kulturo izseljenega managerja. Stopnjo različnosti je mogoče oceniti $\mathrm{s}$ primerjanjem teh kultur na podlagi modelov, kot sta na primer Hofstedejev ali

\section{Tudi managerji se morajo prilagoditi tuji kulturi, ce- prav so $v$ tujini le začasno.} Kluckhohnov in Strodtbeckov model.

Stopnja interakcije s prebivalci gostujoče države je povezana s pogostostjo in ravnjo, na kateri izseljeni manager komunicira $\mathrm{z}$ lokalnim prebivalstvom. Novost pri delu pa se nanaša na zahteve, ki izhajajo iz narave dela, njegovih pričakovanj, omejitev in stopnje samostojnosti ter odgovornosti pri delu.

\section{SKLEPNE MISLI}

Izseljeni managerji se morajo prilagoditi novim delovnim razmeram, interakciji z lokalnim prebivalstvom in na splošno novemu okolju. Organizacija, v kateri so zaposleni, lahko pospeši njihovo prilagoditev tako, da zanje in za njihove družine, če so z njimi, pred odhodom in med opravljanjem nalog organizira ustrezno izobraževanje.

\section{LITERATURA}

Abbasi, S. M., Hollman K. W.: Business Success in the Middle East, Management Decision, 31(1), 1993, str. 55-59.

Francesco, A. M., Gold B. A.: International Organizational Behavior, Prentice Hall, 1998.

Gannon, M. J. and Associates: Understanding Global Cultures: Metaphorical Journeys through 17 Countries, Sage Publications, 1994.

Hofstede, G.: Cultures and organisations, McGraw-Hill, London, 1991.

Kluckhohn, F., Strodtbeck, F. L.: Variations in Value Orientations, Peterson, 1961.
Samovar, L. A., Porter R. E.: Communication between Cultures, Wodsworth, 1991.

Treven, S.: Management človeških virov, Gospodarski vestnik, Ljubljana, 1998.

Treven, S.: Vpliv kulture na organizacijsko vedenje, Naše gospodarstvo, Maribor, št. 2-3, 2000.

Treven, S.: Organizacijsko vedenje: mednarodni pristop, GV Založba, 2001. 